comparison, I have generally found the description of Dr. Baird the most accurate and trustworthy.

To facilitate this object, I have added a list of the species, the skulls of which have been figured.

Fam. Molgide.

Molge striata, Gray, Cat. Batr. p. 31. t. 3. f. 111 ; Schlegel, Fauna Japon. t. 5. f. 9, 10.

\title{
Fam. Plethodontide.
}

Onychodactylus Japonicus, Gray, Cat. Batr. p. 33.t. 3. f. 1 ; Fauna Japon. t. 3. f. 6.

Амвyostoma opacum, Dum. et Bibr. E. Gén. ix. t. 10. f. 6 .

Plethodon glutinosum, Tschudi, Batr. t. 2. f. 4.

Desmognathus fuscus.

Plethodon fuscum, Dum. et Bibr. Erp. Gén. t. 101. f. 3. B.M.

Spelerpes rubra (skull, fig. 3).

“Bolitoglossa rubra, Cab. B.M.” from Paris.

Geotriton fuscus, sp., Dum. et Bibr. E. G. ix. 112. t. 102. f.1.

Edipus variegatus.

Bolitoglossa mexicana, Dum. et Bibr. Erp.Gén. ix. p. 3. t.101. f. 4.

Ensatina Eschscholtzia, Esch. Zool. Atlas, t. 22.

6. On the Power of Dissolving Shells possessed by the Bernard Crab (Pagurus). By Dr. J. E. Gray, F.R.S., V.P.Z.S., Pres. Ent. Soc., Etc.

In a note to my paper " On the Formation and Structure of Shells," in the 'Philosophical Transactions' for 1833, I stated it is probable that some Bernard Crabs have also the faculty of dissolving shells, for it is not unusual to find the long fusiform shells (such as Fusus fasciolanus and turbinella) which are inhabited by these animals, with the inner lip and great part of the pillar on the inside of the mouth destroyed, so as to render the aperture much larger than usual.

Having continued my observations on these shells, I am convinced that certain species of Bernard Crab (Pagurus) have the power, some possessing it to a much greater degree than others.

Lieut. Burnaby lately brought a number of Crustacea to the British Museum from the South Seas; amongst which there were 
several specimens of Paguri in shells, and these shells were more destroyed than any I had before observed. One, a specimen of Persona tuberosa, not only had the whole of the thickened rounded inner lip ; but the whole of the septa between the whorls up to the apex of the shell were also destroyed, so as to convert the shell into a simple conical cavity, and the greater part of the substance of the outer lip was also removed from the inner surface, so as to render the outer part of the shell very thin-indeed so much was removed, that the series of pits on the outer surface, just above the marginal varix of the outer lip, were entirely destroyed, converting the pits into a series of apertures; and the other shells inhabited by these Crustacea were similarly destroyed. The internal surface of the shell has the appearance of being ground away by a file or other rough surface.

\section{Remarks on the British Actiniade, and Re-arrange- ment of the Genera. By W. Thompson.}

Observations extending over many years, on the characters and the habits of the British species of the Actiniada, clearly proved to me that the genera of British Actinia required great alterations; and I submit the present classification as an improvement on those hitherto used.

It is well understood that the principal generic characters are derived from modifications, and differences existing in the tegumentary system and in the tentacula. Dr. Johnston, in his 'History of British Zoophytes,' published in 1847, made but one British genus, Actinia of Linnæus, and in this he included all known British species; but he divided it into two sections or subgenera, the one characterized by having the skin smooth, the other by having the skin covered with porous warts. Mr. Gosse, in a paper read before the Linnean Society in the early part of 1855 , divided the family into three genera; namely, SAGARTIA, destitute of warts, and emitting filaments from pores; BUNODEs, studded with warts, and without pores and filaments; and AстіNis, having a perfectly smooth skin, and destitute of warts, pores or filaments. The character arising from the presence or absence of filaments is not of very great weight, inasmuch as the presence of filaments depends entirely on the presence of pores in the skin, and through which they are extruded; consequently, when there are no pores there are no filaments.

These genera comprised species possessing characters so different from each other, and so well established, that I found they must not remain united. For instance, the genus Sagartia included, amongst others, $A$. dianthus, $A$. bellis and $A$. parasitica; but although the characters were useless as generic distinctives, yet they appear to me to be of sufficient importance to be used as characters for the division of the Actiniada, and I have accordingly used them for that purpose.

No. CCCLVI.-Proceedings of the Zoological Society. 


\section{$2 \mathrm{BHL}$ Biodiversity Heritage Library}

Gray, John Edward. 1858. "ON THE POWER OF DISSOLVING SHELLS POSSED BY THE BERNARD CRAB." Proceedings of the Zoological Society of London 1858, 144-145. https://doi.org/10.1111/j.1469-7998.1858.tb06358.x.

View This Item Online: https://www.biodiversitylibrary.org/item/100585

DOI: https://doi.org/10.1111/j.1469-7998.1858.tb06358.x

Permalink: https://www.biodiversitylibrary.org/partpdf/74092

\section{Holding Institution}

Smithsonian Libraries

\section{Sponsored by}

Biodiversity Heritage Library

\section{Copyright \& Reuse}

Copyright Status: Public domain. The BHL considers that this work is no longer under copyright protection.

This document was created from content at the Biodiversity Heritage Library, the world's largest open access digital library for biodiversity literature and archives. Visit BHL at https://www.biodiversitylibrary.org. 